\title{
KEPADATAN SPONS PADA EKOSISTEM LAMUN KAITANNYA DENGAN PARAMETER OSEANOGRAFI DI PERAIRAN DESA KASWARI KABUPATEN WAKATOBI
}

\section{The Density of Sponges in Seagrass Ecosystem Related to Oceanographic Parameters in The Waters of Kaswari Village Wakatobi District}

\author{
Nasrawati $^{1 *}, \operatorname{Ira}^{2}$, Asmadin $^{2}$ \\ ${ }^{1}$ Program Studi Ilmu Kelautan, ${ }^{2}$ Program Studi Oseanografi \\ FakultasPerikanandanIlmuKelautan,Universitas Halu Oleo, Kendari. \\ Jl. HAE MokodompitKampusBumiTridharmaAnduonohuKendari 93232, Tel/Fax: (0401) 31937821 \\ *Surel : nasrawati@gmail.com
}

\begin{abstract}
Abstrak
Padang Lamun merupakan tempat hidup bagi beragam organisme, salah satunya adalah spons. Tujuan dari penelitian ini yaitu untuk mengetahui keragaman jenis spons dan lamun di perairan Desa Kaswari Kabupaten Wakatobi serta hubungan kepadatan spons dan persentase tutupan lamun kaitannya dengan parameter oseanografi. Penelitian ini dilaksanakan pada bulan Februari-November 2020 dengan lokasi di perairan Desa Kaswari Kabupaten Wakatobi. Metode Penelitian ini menggunakan metode transek kuadran dengan ukuran $1 \times 1 \mathrm{~m}$. Pengamatan dilakukan di tiga stasiun penelitian yang diambil berdasarkan tipe substrat dasar perairan yang berbeda. Analisis keterkaitan antara kondisi spons dan lamun terhadap beberapa parameter oseanografi dianalisis menggunakan Analisis Komponen Utama (AKU). Hasil penelitian menunjukkan bahwa jenis spons yang ditemukan yaitu Agelas citrina, Agelas conifera, Amphimedon viridis, Clathria reinwardti, Chondrilla caribensis, Haliclona oculata dan Tectitethya crypta. Jenis lamun yang ditemukan yaitu Thalassia hemprichii, Enhalus acoroides dan Cymodocea rotundata. Hasil studi menunjukkan bahwa persentase tutupan lamun sebesar 76.50, 51.83 dan 41.00\% memiliki hubungan yang sangat kuat terhadap kepadatan spons sebesar 7.47, 6.17 dan $4.60 \mathrm{ind} / \mathrm{m}^{2}$. Semakin tinggi persentase tutupan lamun menunjukkan semakin tinggi kepadatan spons. Parameter oseanografi seperti kecepatan arus memiliki hubungan berbanding terbalik (berpengaruh) terhadap kepadatan spons dan persentase tutupan lamun.
\end{abstract}

Kata Kunci : Spons, lamun, parameter oseanografi, perairan Kaswari, Wakatobi.

\begin{abstract}
Seagrass beds are a place to live for various organisms, one of which is a sponge. The purpose of this study is to determine the diversity of sponge and seagrass species and the relationship between sponge density and the percentage of seagrass cover with oceanographic parameters in the waters of Kaswari Village, Wakatobi Regency. This research was conducted in February-November 2020 with a location in the waters of Kaswari Village, Wakatobi Regency. Methods This research uses the quadrant transect method with a size of $1 \times 1 \mathrm{~m}$. Observations were made at three research stations based on different types of the bottom substrate. Analysis of the relationship between the conditions of sponges and seagrass to several oceanographic parameters was analyzed using Principal Component Analysis (AKU). The results showed that the species of sponges found were Agelas citrina, Agelas conifera, Amphimedon viridis, Clathria reinwardti, Chondrilla caribensis, Haliclona oculata, and Tectitethya crypta. The species of seagrass found were Thalassia hemprichii, Enhalus acoroides, and Cymodocea rotundata. The study results showed that the percentage of seagrass cover of 76.50, 51.83, and $41.00 \%$ had a very strong relationship with sponge density of 7.47, 6.17 , and 4.60 ind / $\mathrm{m}^{2}$. The higher the percentage of seagrass cover, the higher the density of the sponge. Oceanographic parameters such as current velocity which has an inversely related (effect) on sponge density and the percentage of seagrass cover.
\end{abstract}

Keywords: Sponge, Seagrass, Oceanographic parameters, Kaswari waters, Wakatobi

\section{Pendahuluan}

Spons adalah organisme multiseluler, tergolong dalam Filum Porifera yang dibagi menjadi 3 kelas yaitu Calcarea, Hexactinellida dan Demospongiae. Di dunia ada sekitar 15.000 spesies hidup di semua habitat laut dan air tawar (Hooper dan Rob, 2002). Spons yang berhasil diinventarisasi di perairan Indonesia masih belum maksimal meskipun telah ditemukan sekitar 850-1500 spesies
(Hooper et al., 2002; De Voogd dan Van Soest, 2002). Umumnya berbagai jenis Spons ditemukan hidup tidak hanya pada ekosistem terumbu karang, tetapi juga pada ekosistem lamun (Wulff, 2008; Samira dkk., 2016). Bahkan beberapa spesies spons di terumbu karang memperluas distribusi habitatnya ke ekosistem lamun (Wulff, 2008). Spons cenderung memilih kondisi lamun berukuran 
besar dengan kerapatan yang cukup tinggi sebagai area perlindungan terhadap gelombang dan predator (Wulff, 2008; Samira $d k k$., 2016; Irfan 2018).

Beberapa studi sebelumnya mengidentifikasi keberadaan spons berdasarkan kondisi oseanografi fisika-kimia perairan (Haris $d k k$., 2014). Keanekaragaman jenis spons pada suatu habitat umumnya ditentukan oleh kondisi perairan yang jernih dan tidak memiliki arus kuat (Haedar $d k k$., 2016). Kedalaman air, pH dan salinitas berpengaruh pada kelimpahan spons dalam suatu ekosistem (Appadoo et al., 2011). Spons merupakan hewan yang memiliki banyak manfaat bagi kehidupan manusia, salah satunya dalam bidang farmasi (Remya et al., 2010). Hasil pengujian aktivitas hambat spons terhadap beberapa bakteri menunjukkan bahwa sekitar 7 jenis spons yang berasal dari ekosistem lamun menunjukkan potensi antibakteri (Samira $d k k ., 2016)$.

Ekosistem pesisir di perairan Desa Kaswari Kabupaten Wakatobi. terdiri dari ekosistem mangrove, lamun dan karang yang masih sangat alami. Keanekaragaman biota lautnya masih jarang di ketahui potensi dan manfaatnya, salah satunya adalah spons yang ada di ekosistem lamun. Berbagai informasi studi di perairan Wakatobi tentang jenis spons di ekosistem lamun tersebut belum banyak diketahui. Oleh karena itu, studi spesifik mengenai komposisi jenis spons dan tutupan lamun kaitannya dengan parameter oseanografi di perairan tersebut menjadi penting untuk dikembangkan menjadi tujuan penelitian ini.

\section{Bahan dan Metode}

Penelitian ini dilaksanakan pada Februari-November 2020 bertempat di perairan desa Kaswari, Kabupaten Wakatobi, Sulawesi Tenggara. Analisis substrat dan bahan organik kolom air dilakukan di Laboratorium Produktivitas dan Lingkungan Perairan (PROLINK), Fakultas Perikanan dan Ilmu Kelautan Universitas Halu Oleo. Peta lokasi penelitian selengkapnya disajikan pada Gambar 1.

Penentuan stasiun ditetapkan berdasarkan karakteristik tipe substrat dasar perairan yang menjadi habitat lamun. Stasiun 1 , tipe substrat lempung liat berpasir, tepatnya berhadapan langsung dengan ekosistem mangrove berada pada titik koordinat 533'28.99" LS- $123^{\circ} 45^{\prime} 43.17^{\prime \prime}$ BT. Stasiun 2, tipe substrat lempung berpasir, tepatnya berada pada sisi kiri dermaga berada pada titik koordinat $5^{\circ} 33^{\prime} 41.32^{\prime \prime}$ LS $123^{\circ} 45^{\prime} 52.58^{\prime \prime}$ BT. Stasiun 3, tipe substrat lempung, tepatnya berhadapan langsung dengan rumah penduduk serta sebagai jalur aktivitas nelayan untuk bepergian ke laut lepas berada pada titik koordinat 5³3'48.92"LS - $123^{\circ} 46^{\prime} 1.33^{\prime \prime}$ BT.

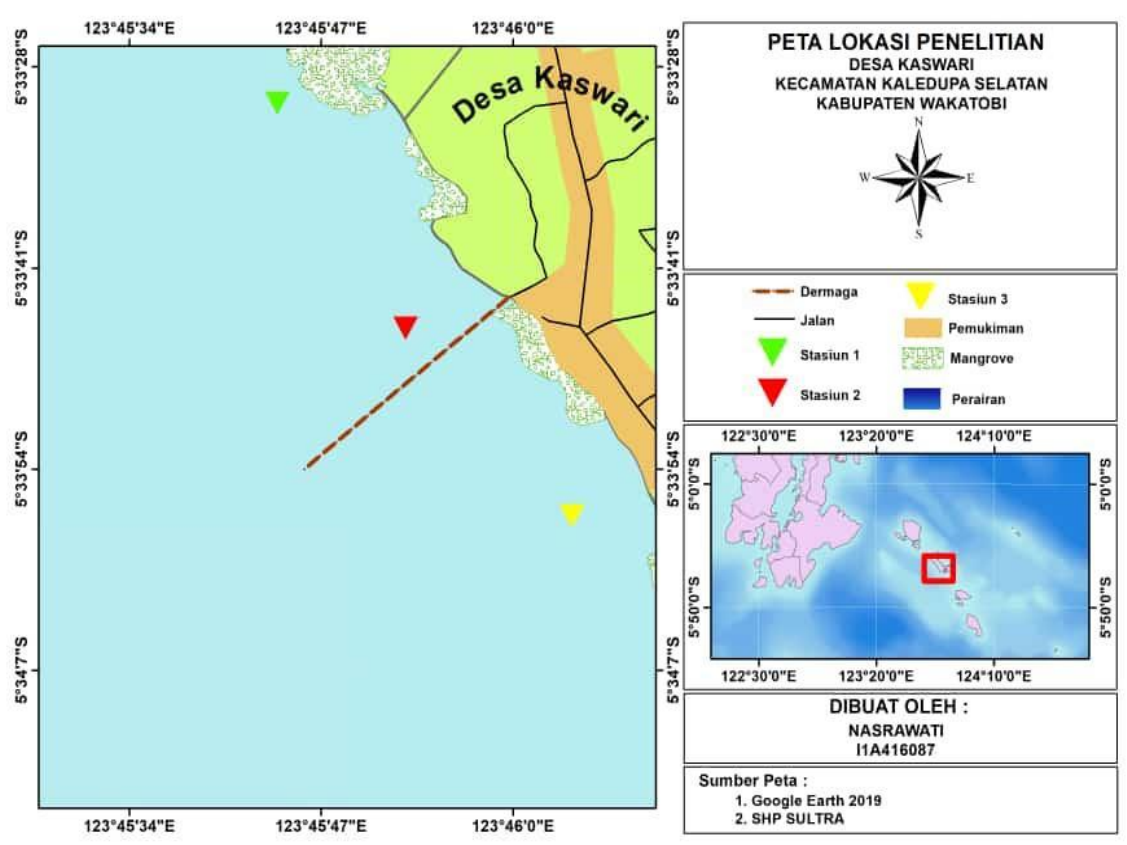

Gambar 1. Peta lokasi penelitian 
Pengamatan data spons dan lamun secara bersamaan menggunakan metode transek kuadran. Setiap jenis spons dan lamun dikumpulkan dalam transek kuadrat $1 \times 1 \mathrm{~m}^{2}$, diidentifikasi dan dihitung jumlahnya. Pengamatan tersebut dilanjutkan pada transek-transek berikutnya di sepanjang bentangan garis transek menggunakan Roll meter sepanjang $50 \mathrm{~m}$. Peletakan transek secara zig-zag dengan jarak antara kuadrat satu dengan yang lainnya adalah $5 \mathrm{~m}$ sebagaimana ditampilkan pada Gambar 2. Identifikasi spons mengacu pada buku John N.A. Hooper \& Robert W.M. Van Soest (2002) dan portal identifikasi sponshttp://spongeguide.org dan http://www .marinespecies.org

/porifera/porifera.php? $\mathrm{p}=$ specimens $\quad$ (Samira $d k k$., 2016). Hasil identifikasi jenis lamun yang ditemukan dalam transek kuadran yaitu dicatat jenisnya dan persen penutupan lamun mengacu pada Hutomo dan Anugerah (2014).

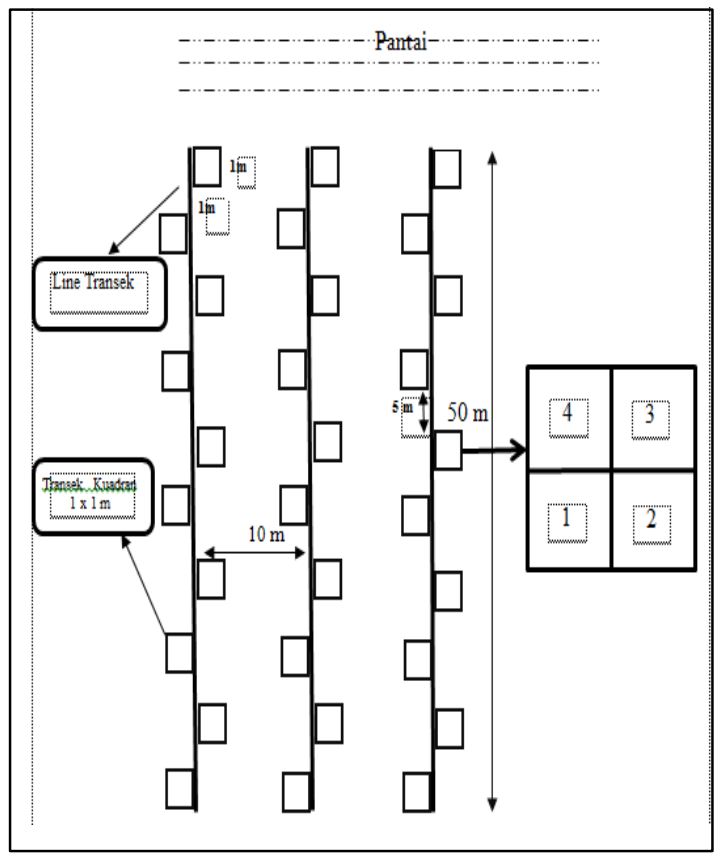

Gambar 2. Plot pengamatan spons dan lamun

Data oseanografi diukur secara langsung (in-situ) dan analisis di laboratorium (ex-situ) meliputi data parameter:

1. Suhu menggunakan alat termometer dengan cara mencelupkan ujung termometer ke dalam badan perairan hingga angka yang tertera pada termometer menunjukkan nilai konstan/stabil (Haedar $d k k ., 2016)$.
2. Kecepatan arus dilakukan dengan alat layang-layang arus dan stopwatch yang datanya diperoleh dengan cara menghitung selang waktu (t) yang dibutuhkan layang arus untuk menempuh jarak (s) (Haedar $d k k ., 2016)$.

3. Salinitas perairan diukur dengan dengan cara meneteskan sampel air laut kedalam prisma hand refraktometer, kemudian tutup plat cahaya dan dicatat nilai salinitas yang tercantum pada alat tersebut (Bella dan Aunurohim, 2013).

4. $\mathrm{pH}$ perairan diukur dengan cara mencelupkan potongan kertas lakmus ke dalam sampel air laut lalu dikeringkan dan kertas $\mathrm{pH}$ dicocokkan warnanya dengan indikator warna $\mathrm{pH}$ untuk mendapatkan nilai $\mathrm{pH}$ air laut (Haedar $d k k$., 2016).

5. Bahan organik kolom air dengan mengambil sampel air laut menggunakan botol sampel berupa kaca (botol terang). Botol diisi air laut sampai memenuhi botol, kemudian memberi label pada setiap botol. Dilakukan sebanyak 3 kali ulangan untuk masing-masing stasiun. Sampel dibawa ke laboratorium untuk dilakukan analisa dengan menggunakan spektrofotometer dengan menggunakan metode titrasi.

6. Substrat dasar perairan ditentukan dengan cara mengambil substrat menggunakan pipa paralon yang berdiameter $5 \mathrm{~cm}$. Pipa paralon dibenamkan dalam substrat dengan kedalaman $10 \mathrm{~cm}$ lalu diangkat, kira-kira 100 gram sampel substrat (Lisdawati $d k k$., 2018). Kemudian dimasukkan dalam kertas sampel untuk dilakukan analisis di laboratorium dengan menggunakan metode pipet.

\section{Analisis Data}

Pengolahan data kepadatan jenis spons, persentase tutupan lamun dan pengukuran parameter oseanografi menggunakan persamaan-persamaan:

\section{Kepadatan Jenis Spons}

Kepadatan jenis spons dihitung dengan menggunakan rumus Brower dan Zar (1997): $\mathrm{N}=\frac{\mathrm{n}}{\mathrm{A}}$

Keterangan :

$\mathrm{N}=$ Kepadatan individu ( $\left.\mathrm{Ind} / \mathrm{m}^{2}\right)$

$\mathrm{n}=$ Jumlah individu yang diperoleh tiap stasiun (Ind)

A $=$ Luas daerah pengamatan $\left(\mathrm{m}^{2}\right)$

2. Persentase Tutupan Lamun 
Persentase tutupan lamun dihitung berdasarkan formula Tebaiy $d k k .,(2014): \mathrm{C}=$ $\frac{\Sigma(C i)}{\mathrm{N}}$

Keterangan:

$\mathrm{C}=$ penutupan jenis lamun ke-i $(\%)$

$\mathrm{Ci}=$ persen penutupan lamun pada tiap plot

$\mathrm{N}=$ jumlah plot transek di setiap sub stasiun

Tabel 1. Kategori tutupan lamun

\begin{tabular}{cl}
\hline Persentase & Kategori \\
Penutupan $(\%)$ & Jarang \\
\hline $0-25$ & Sedang \\
$26-50$ & Padat \\
$51-75$ & Sangat Padat \\
$76-100$ &
\end{tabular}

Sumber: Coremap-Lipi (2014)

3. Parameter Lingkungan

a. Kecepatan Arus

Kecepatan arus dihitung berdasarkan Triatmodjo (1999) mengikuti persamaan (3) berikut:

$\mathrm{V}=\mathrm{s} / \mathrm{t}$

Keterangan :

$\mathrm{V}=$ Kecepatan arus $(\mathrm{m} / \mathrm{s})$

$\mathrm{s}=$ Panjang tali $(\mathrm{m})$

$\mathrm{t}=$ Waktu yang diperlukan untuk tali menegang (s)

b. Bahan Organik Kolom Air

Perhitungan kandungan bahan organik total menggunakan Allen et al., (1976) dalam persamaan (4):

$\mathrm{Li}=\frac{\mathrm{Wo}-\mathrm{Wt}}{\mathrm{Wo}} \times 100 \%$

Keterangan :

$\mathrm{Li}$ : Losonignation (\%)

Wo : Berat awal (gram)

Wt : Berat akhir (gram)

c. Korelasi persentase tutupan lamun dan kepadatan spons

Derajat hubungan antara persentase tutupan lamun (variabel X) dan kepadatan spons (variabel Y) dapat dinyatakan dalam besarnya koefisien korelasi $(r)$ menggunakan rumus Sugiyono (2013) dalam persamaan (5):

$r=\frac{N \sum X Y-\sum X \sum Y}{\sqrt{\left(N \sum X^{2}-\left(\sum X\right)^{2}\left(N \sum Y^{2}-\left(\sum Y\right)^{2}\right)\right.}}$

Keterangan :

$\mathrm{r}=$ Koefisien korelasi linear

$\mathrm{N}=$ Jumlah data

$\mathrm{X}=$ Variabel dependen (persentase tutupan lamun)

$\mathrm{Y}=$ Variabel independen (kepadatan spons)

Data komposisi jenis spons dan lamun dianalisis secara deskriptif dengan bantuan tabel dan gambar menggunakan Microsoft Excel 2010. Analisis hubungan antara kepadatan spons dan persentase tutupan lamun dianalisis secara regresi linear sederhana menggunakan Microsoft Excel 2010. Hubungan persentase tutupan lamun dan kepadatan spons terhadap kualitas lingkungan beberapa parameter oseanografi dianalisis menggunakan Principal Component Analysis (PCA) dengan bantuan software XLSTAT 2016.05.

\section{Hasil dan Pembahasan}

Hasil identifikasi jenis spons ditemukan sebanyak 5 ordo 5 family dan 7 spesies. Spesies tersebut terdiri dari A. conifera, A. citrina, A. viridis, $C$. reinwardti, $\quad$. caribensis, $H$. oculata dan T. crypta. Semua spons yang ditemukan tersebut termasuk kedalam kelas Demospongiae. Dominasi kelas tersebut sesuai studi Marzuki (2018) dapat mendominasi lebih dari $90 \%$ spesies spons.

Jenis lamun yang ditemukan sebanyak 3 jenis, yaitu $E$. acoroides, $T$. hemprichii dan $C$. rotundata. Komunitas lamun pada area studi termasuk dalam tipe vegetasi lamun campuran. Tipe komunitas tersebut sesuai Billy $d k k$., (2013) bahwa terdapat sekitar 2 sampai 12 jenis lamun yang tumbuh bersama-sama pada satu substrat.

Tabel 2. Kepadatan jenis spons di perairan Desa Kaswari Kabupaten Wakatobi

\begin{tabular}{clccc}
\hline \multirow{2}{*}{ No } & \multicolumn{2}{c}{ Spesies } & \multicolumn{3}{c}{ Kepadatan Spons (individu $/ \mathrm{m}^{2}$ ) } \\
& Amphimedon viridis & 0.2 & 0.13 & 0.37 \\
\hline 1 & Agelas citrine & 1.07 & 0.53 & 0.57 \\
2 & A. conifer & 4.2 & 3.83 & 2.4 \\
3 & Tectitethya crypta & 0.97 & 0.57 & 0.3 \\
4 & Haliclona oculata & 0.77 & 0.8 & 0.7 \\
5 & Clathria reinwardtii & 0.27 & 0.2 & 0.23 \\
6 & Chondrilla caribensis & 0 & 0.1 & 0.03 \\
7 & Jumlah & 7.47 & 6.17 & 4.60 \\
\hline
\end{tabular}


Tabel 3. Kondisi tutupan lamun di area penelitian

\begin{tabular}{clccc}
\hline \multirow{2}{*}{ No } & \multirow{2}{*}{ Jenis Lamun } & \multicolumn{3}{c}{ Persentase tutupan Lamun (\%) } \\
\cline { 3 - 5 } & & Stasiun I & Stasin II & Stasiun III \\
\hline \multirow{2}{*}{1} & Thalassia hemprichii & 43.00 & 27.00 & 14.50 \\
2 & Cymodocea rotundata & 22.00 & 8.83 & 6.50 \\
3 & Enhalus acoroides & 11.50 & 16.00 & 20.00 \\
\hline & Total & 76.50 & 51.83 & 41.00 \\
\hline & Kategori & Sangat padat & Padat & Sedang \\
\hline
\end{tabular}

Tingkat kepadatan jenis spons disajikan pada Tabel 2. Tingkat kepadatan spons berkisar $4.60-7.47 \mathrm{ind} / \mathrm{m}^{2}$ di setiap stasiun. Nilai ini jauh lebih tinggi dari yang dilaporkan Haris dkk., (2014) di perairan Kepulauan Spermonde Kota Makassar sebesar 0.96-4.00 ind $/ \mathrm{m}^{2}$. Hasil studi menunjukkan bahwa kepadatan jenis tertinggi berkisar 2.4-4.2 ind $/ \mathrm{m}^{2}$ adalah A. conifera. Jenis tersebut ditemukan hidup berkoloni pada rongga di dalam ekosistem lamun atau di sela-sela kumpulan lamun yang cukup padat. Menurut Irfan (2018) bahwa jenis spons tersebut cenderung memilih kondisi padang lamun dengan kerapatan yang cukup tinggi serta mampu beradaptasi terhadap gelombang dan arus. Kepadatan jenis Spons terendah berkisar 0-0.10 ind $/ \mathrm{m}^{2}$ adalah C. caribensis ditemukan hanya di stasiun II dan III. Hal ini diduga karena spons jenis ini preferensinya sebagaimana dilaporkan Sari (2014) lebih menyukai kondisi perairan yang terbuka atau terpapar langsung oleh matahari dan dijumpai hidup pada lamun yang penutupannya rendah. Gambaran kondisi tersebut ditemukan pada kedua stasiun tersebut.

Kondisi tutupan lamun di seluruh stasiun penelitian disajikan pada Tabel 3 . Tabel tersebut menunjukkan bahwa persentase tutupan lamun terbesar terdapat pada stasiun I. Kondisi tersebut disebabkan spesies lamun T. hemprichii dan E. acoroides adalah jenis lamun yang mampu beradaptasi dengan baik dan memiliki daya tahan terhadap berbagai kondisi lingkungan. Tipe substrat dasar perairan Desa Kaswari memiliki tingkat kehalusan yang sangat tinggi. Menurut Riski, dkk., (2016) kondisi substrat dengan tingkat kehalusan yang sangat tinggi memungkinkan lamun dapat tumbuh dan berkembang dengan baik, dan mudah menancapkan akar ke dalam substrat serta menyerap unsur-unsur hara yang ada di substrat sedimen oleh kualitas habitat lamun pada stasiun tersebut memiliki tekstur sedimen dengan fraksi jenis liat lebih banyak, sehingga bahan organik akan lebih banyak berikatan dengan sedimen di stasiun ini dibandingkan dengan stasiun lainnya. Kondisi seusai menurut Irfan (2018) bahwa kandungan bahan organik yang tinggi pada perairan akan menghasilkan nutrien yang lebih banyak, dimana nutrien dibutuhkan oleh tumbuhan seperti lamun untuk pertumbuhan dan perkembangan hidupnya. Ira $d k k$., (2012) menyatakan bahwa $T$. hemprichii dan $E$. acoroides memiliki jumlah persentase tutupan yang jauh lebih tinggi dibandingkan dengan C. rotundata. Penyebabnya adalah karena kedua jenis lamun tersebut memiliki ukuran daun panjang dan lebar, sehingga terlihat lebat serta lebih banyak menutupi luasan area. Kondisi ini sesuai menurut Sari (2018) bahwa tutupan jenis lamun dipengaruhi oleh lebar daun lamun, padang lamun yang terlihat penuh dan lebat memiliki tutupan yang tinggi, karena daunnya besar dan lebar.

Hasil analisis hubungan antara spons dan lamun menunjukkan bahwa semakin tinggi persentase tutupan lamun, maka kepadatan spons semakin meningkat. Hubungan keduanya dapat ditunjukkan melalui persamaan regresi linear $\mathrm{y}=0.076 \mathrm{x}+$ 1.79 berdasarkan Gambar 3. Dari persamaan tersebut diperoleh nilai koefisien korelasi (r) $=0.96$ dan koefisien determinasi $\left(\mathrm{R}^{2}\right)=$ 0.9259. Nilai koefisien korelasi menunjukkan hubungan positif antara persentase tutupan lamun dengan kepadatan spons dengan tingkat hubungan sangat kuat sebagaimana diacu dari Sugiyono (2013), jika nilai korelasi 0.80 - 1.00 maka variabel bebas (tutupan Lamun) memiliki hubungan sangat kuat terhadap variabel terikat (kepadatan spons). Dalam penelitian ini ditemukan jumlah individu dari tiap jenis Spons cukup banyak, terutama pada area ekosistem lamun dengan kondisi padat dan ukuran lebih besar. Kondisi ini sesuai dengan pernyataan Samira dkk., (2016) bahwa adanya jenis lamun berukuran 
besar serta lebih padat memberi perlindungan terhadap spons dari paparan gelombang maupun predator, dan sebagai penjebak detritus yang membantu mekanisme penyaringan makanan spons melalui pori di permukaan tubuhnya. Spons cenderung memilih kondisi padang lamun dengan persentase tutupan yang cukup tinggi karena akan membantu mengurangi efek turbulensi perairan dan memberikan tempat berlindung bagi spons dari banyak faktor yang dapat mengganggu kehidupannya.

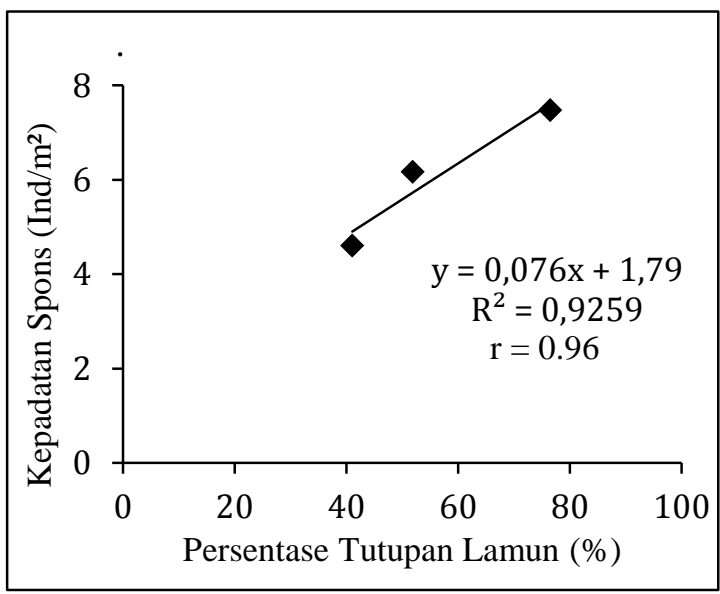

Gambar 3. Hubungan kepadatan spons dan persentase tutupan lamun

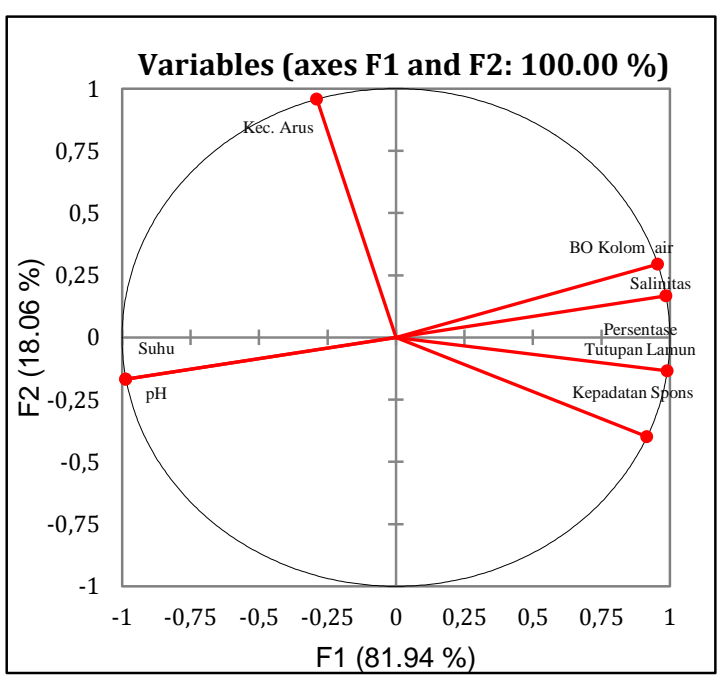

Gambar 5. Hasil analisis PCA hubungan antara kepadatan spons dan persentase tutupan lamun dengan parameter oseanografi.

Hasil Principal Component Analysis dalam penelitian ini menunjukkan tingkat keeratan hubungan antara Spons dan Lamun terhadap beberapa parameter oseanografi pada area studi. Berdasarkan analisis PCA yang ditunjukkan berdasarkan grafik biplot pada Gambar 5 terlihat bahwa ketujuh variabel tersebut menunjukkan pengaruh yang berbeda-beda. Variabel kepadatan spons dan persentase tutupan lamun berada pada kuadran yang sama menunjukkan bahwa kedua variabel tersebut mempunyai hubungan kekerabatan yang dekat. Kedua variabel tersebut berkerabat dekat juga dengan variabel $\mathrm{BO}$ kolom air dan salinitas yang berada pada kuadran yang berbeda akan tetapi membentuk sudut lancip $<90^{\circ}$. Sedangkan untuk variabel suhu, $\mathrm{pH}$ dan kecepatan arus berada pada kuadran yang berbeda dengan sudut $>90^{\circ}$ dan saling bertolak belakang dari variabel-variabel yang berdekatan. Hal ini pula dibuktikan dengan matriks korelasi dari variabel-variabel tersebut dimana salinitas dan BO kolom air berkorelasi positif terhadap kepadatan spons dan persentase tutupan lamun sedangkan suhu, $\mathrm{pH}$ dan kecepatan arus berkorelasi negatif.

Variabel BO kolom air dan salinitas mempunyai hubungan kekerabatan yang sangat dekat dengan kepadatan spons dan persentase tutupan lamun yang berada pada kuadran yang berbeda akan tetapi membentuk sudut lancip $<90^{\circ}$. Spons adalah organisme bentik yang termasuk dalam plankton feeder. Kandungan $\mathrm{BO}$ dalam kolom air dimanfaatkan oleh spons dijadikan sebagai bahan makanan untuk tumbuh dan berkembang. Kandungan BO kolom air $(40.76 \mathrm{mg} / \mathrm{L})$ pada stasiun I jauh lebih tinggi dibanding stasiun II $(36.34 \mathrm{mg} / \mathrm{L})$ dan III (36.97 mg/L). BO dalam kolom air berkorelasi positif dengan Spons (0.75) dan Lamun (0.90). Tingginya BO dalam kolom air diduga berasal dari sumbangan serasah mangrove dan tutupan lamun yang cukup padat di area tersebut. Bahan organik dalam kolom air menurut Sari (2018) dapat berasal dari kumpulan serasah lamun yang terurai di perairan. Menurut Suparno dkk., (2009) bahwa ketersediaan makanan yang banyak dalam bentuk bahan organik terlarut akan memicu pertumbuhan spons yang tinggi. Ketersediaan makanan bagi Spons cukup besar, kondisi ini diperkuat dengan rata-rata ditemukannya Spons di setiap stasiun, meskipun tingkat kepadatan Spons rata-rata cukup tinggi $\left(7,47 \mathrm{ind} / \mathrm{m}^{2}\right)$ pada stasiun I dibanding stasiun lainnya (Tabel 2). 
Salinitas berkorelasi positif dengan spons (0.83) dan lamun (0.95). Salinitas perairan di tiga stasiun penelitian berkisar antara 34-35 \%. Kisaran nilai salinitas tersebut tidak jauh berbeda dan masih dalam batas toleransi salinitas optimum bagi kehidupan organisme spons dan lamun. Beberapa studi melaporkan kondisi optimum salinitas, diantaranya studi De Voogd (2005) bahwa spons hidup pada kisaran salinitas 28-38\%o. Menurut Lisdawati $d k k$., (2018) bahwa salinitas yang optimum untuk lamun adalah $35 \%$.

Berdasarkan nilai matriks korelasi diperoleh bahwa suhu dengan kepadatan spons berkorelasi negatif (-0.83), suhu dengan persentase tutupan lamun berkorelasi negatif (0.95). Korelasi negatif dari dua variabel berbeda menunjukkan hubungan dengan arah yang berlawanan. Pada area studi, Spons tumbuh dengan baik pada kisaran suhu 29 $30.67{ }^{\circ} \mathrm{C}$ masih cukup relevan dengan suhu optimal $26-31{ }^{\circ} \mathrm{C}$ dari studi De Voogd (2005). Selain itu suhu perairan tersebut cukup mendukung pertumbuhan dan proses fotosintesis bagi ekosistem Lamun, seperti dilaporkan dalam Billy dkk., (2013) bahwa suhu yang baik berkisar $28-30 \quad{ }^{\circ} \mathrm{C}$ bagi pertumbuhan lamun dan $35{ }^{\circ} \mathrm{C}$ untuk proses fotosintesis.

Matriks korelasi antara nilai $\mathrm{pH}$ dan kepadatan spons berkorelasi negatif (-0.83) dan dengan persentase tutupan lamun berkorelasi negatif (-0.95). Berdasarkan analisis PCA kedua variabel berkorelasi negatif terhadap objek penelitian, Semua nilai $\mathrm{pH}$ perairan diperoleh sebesar 6 . Kondisi ini masih cukup sesuai bagi kehidupan spons dan lamun. Kehidupan dalam air menurut Effendi (2003) masih dapat bertahan bila perairan mempunyai kisaran $\mathrm{pH}$ 5-9. $\mathrm{pH}$ dan suhu pada stasiun I terlihat lebih rendah sebab pada saat pengambilan data di lapangan terjadi hujan sehingga nilai suhu dan $\mathrm{pH}$ menurun.

Matriks kecepatan arus berkorelasi negatif terhadap kepadatan spons $(-0.64)$ dan persentase tutupan lamun (-0.41). Kecepatan arus pada stasiun III $(0.103 \mathrm{~m} / \mathrm{s})$ memiliki nilai lebih tinggi dibanding stasiun I $(0.087 \mathrm{~m} / \mathrm{s})$ dan II $(0.062 \mathrm{~m} / \mathrm{s})$. Hal ini disebabkan stasiun III berdekatan dengan perairan Desa Peropa yang diduga mendapat pengaruh langsung. Perairan di desa tersebut kecepatan arusnya lebih kuat, karena sebagian pantainya dilengkapi pemecah ombak dan posisinya relatif terbuka dan berhadapan langsung dengan laut Flores. Selain itu stasiun tersebut tidak memiliki penghalang seperti Dermaga pada stasiun I dan II. Kondisi tersebut memperlihatkan bahwa kondisi arus di area studi masih berperan penting terhadap pertumbuhan Spons dan Lamun. Kebanyakan spons tumbuh subur pada arus yang lebih tenang (Suharyanto, 2008) dan pada kecepatan arus perairan $<1 \mathrm{~m} / \mathrm{s}$ (Amri (2017). Arus juga berperan penting bagi pertumbuhan organisme, karena arus membawa nutrisi dan makanan yang dibutuhkan oleh organisme. Menurut Ira $d k k$., (2012) bahwa kecepatan arus yang tinggi juga mempengaruhi kerapatan jenis lamun, sebab tingginya kerapatan jenis lamun akan mempengaruhi tingginya persen penutupan lamun.

Berbagai parameter diatas, terutama suhu, arus, salinitas dan BO kolom air menurut Storr (1976) merupakan faktor pembatas terhadap pertumbuhan spons yang berpengaruh terhadap keseimbangan jumlah kepadatan spons. Spons hidup secara sessil yang artinya melekat dan menetap pada suatu substrat. Selain faktor pembatas tersebut, kondisi substrat juga mempengaruhi pertumbuhan spons, yang tidak hanya bergantung pada jumlah sedimen, ukuran partikel dan mineralogy (Bannister et all., 2012). Hasil analisis tipe substrat menunjukkan adanya dominasi partikel tertentu, terutama pasir $69.09 \%$ pada stasiun I dan $78 \%$ untuk stasiun II dari pada dominasi debu $40.63 \%$ pada stasiun III. Hal menariknya adalah tipe substrat pada Stasiun I lempung liat berpasir memiliki tingkat kepadatan spons dan persentase tutupan lamun tertinggi. Kondisi ini relevan dengan pendapat Wulff (2008) bahwa spons hidup pada ekosistem padang lamun yang berukuran besar dengan kerapatan yang cukup tinggi serta substrat yang di dominasi oleh pasir halus. Meskipun pada Stasiun III didominasi oleh substrat halus dengan kategori substrat lempung, akan tetapi banyak partikel-partikel kecil yang menutup pori-pori spons, sehingga menghambat pertumbuhannya. Disamping itu pula, stasiun III merupakan jalur aktivitas transportasi laut nelayan, sehingga pada stasiun ini sering terjadi pengadukan oleh dayung atau perahu motor. Kondisi ini sesuai menurut Irfan, (2018) bahwa pengadukan mudah terjadi pada substrat yang didominasi oleh pasir halus yang menyebabkan banyak padatan tersuspensi dengan ukuran partikel lebih kecil menutup lubang oskula dan ostia spons, sehingga mengganggu aliran air pada pori-pori spons. 


\section{Simpulan}

Komposisi jenis spons yang ditemukan berasal dari kelas Demospongiae, dibagi ke dalam 5 Ordo, 5 Family, 6 Genus dan 7 Spesies yaitu Agelas citrina, A. conifera, A. viridis, $C$. reinwardti, $C$. caribensis, $H$. oculata dan $T$. crypta. Komposisi jenis lamun diperoleh dari kelas Angiospermae, yang terbagi ke dalam 1 Ordo, 2 Family, 3 Genus dan 3 Spesies, yaitu T. hemprichii, E. acoroides dan $C$. rotundata. Persentase tutupan lamun memiliki hubungan yang sangat kuat terhadap kepadatan spons. Semakin tinggi persentase tutupan lamun, maka semakin tinggi kepadatan spons. Berdasarkan analisis PCA terdapat keterkaitan antara parameter oseanografi, terutama kecepatan arus yang memiliki pengaruh hubungan berbanding terbalik dengan kepadatan spons dan persentase tutupan lamun.

\section{Ucapan Terima kasih}

Penulis mengucapkan terima kasih kepada teman-teman seperjuanganku tim peneliti Desa Kaswari dan kakak Yogi Irawan, S.Si., yang telah membantu dalam pengambilan data sehingga penelitian dapat terlaksana dengan baik. Terimakasih juga kepada pihak laboratorium prolingk fakultas perikanan universitas halu oleo yang telah membantu dalam analisis sampel.

\section{Daftar Pustaka}

Appadoo C., Sandeep S B dan Daniel M. 2011. Study of Physico - Chemical Parameters Affecting The Distribution Of Sponge Xestospongia Exigua (Phylum Porifera, Class Demospongiae) in a Northern Lagoon of Mauritius. Journal of Environmental Research and Development. Vol. 5 (3A): 741-748.

Aryono T H., Muhammad H., Hadiyanto., Agus B dan Rikoh M S. 2018. Shallow Water Sponges Along the South Coast of Java, Indonesia. Biodiversitas. Vol 19 (2): 535-543.

Bannister R., Battershill C dan De Nys R. 2012. Suspended sediment grain size and mineralogy across the continental shelf of the Great Barrier Reef: impacts on the physiology of a coral reef sponge. Cont. Shelf Res. 32: 86-95.
Bella I S dan Aunurohim. 2013. Struktur Komunitas Spons Laut (Porifera) di Pantai Pasir Putih, Situbondo. Jurnal Sains dan Seni Pomits .Vol. 2 (2): 2337 3520 .

Billy T., Wagey dan Webi S. 2013. Variasi Morfometrik Beberapa Jenis Lamun di Perairan Kelurahan Tongkeina Kecamatan Bunaken. Jurnal Pesisir dan Laut Tropis. Vol 3(1):36-44.

Brower S dan JE Zar JH. 1997. Field and Laboratory Method For General Ecology. Wm, C Broun Publishing Dubukue. Lowa. Hal 151- 169.

COREMAP-LIPI. 2014. Panduan Monitoring Padang Lamun. Pusat Penelitian Oseanografi LIPI, Jakarta.

De Voogd N J., Becking L E dan Cleary D F R. 2009. Sponge Community Composition in the Derawan Islands, NE Kalimantan, Indonesia. Marine Ecology Progress Series Vol. 396:169-180.

De Voogd N J., Cleary D F R., Hoeksema B W., Noor A dan Van Soest R W M. 2006. Sponge Beta Diversity in the Spermonde Archipelago, SW Sulawesi, Indonesia. Marine Ecology Progress Series 309: 131-142.

De Voogd NJ, Daniel F R C. 2008. An Analysis of Sponge Diversity and Distribution at Three Taxonomic Levels in the Thousands Islands/ Jakarta Bay reef complex, West-Java, Indonesia. Marine Ecology 29: 205-215. ISSN 0173-9565.

De Voogd NJ. 2005. Indonesian sponges: biodiversity and mariculture potential [Disertasi]. Netherlands: University of Amsterdam.

De Voogd, N.J. \& Van Soest R W M. 2002. Indonesian Sponges of the Genus Petrosia Vosmaer (Demospongiae: Haplosclerida). Zool. Med. Leiden 76 (16) 30 ix : 193-209. ISSN 0024-0672.

Effendi H. 2003. Telaah Kualitas Air Bagi Pengelolaan Sumberdaya dan Lingkungan Perairan. Yogyakarta (ID): Kanisius.

Haedar., Baru S \& Ratna D P. 2016. Potensi Keanekaragaman Jenis dan Sebaran Spons di Perairan Pulau Saponda Laut Kabupaten Konawe. Jurnal Sapa Laut. Vol 1 (2): 1-9.

Happy I S., Ricky R dan Marindah Y I. 2018. Dampak Perubahan Penggunaan Lahan 
Terhadap Kondisi Padang Lamun di Perairan Timur Pulau Bintan Kepulauan Riau. Jurnal Segara Vol.14 (1): 1-10. ISSN : 1907-0659.

Haris A., Shinta W., Sulaiman G dan Andry M. 2014. Komposisi Jenis dan Kepadatan Sponge (Porifera: Demospongiae) di Kepulauan Spermonde Kota Makassar. Biota Vol. 19 (1): 36-42. ISSN: 0853-8670.

Hooper J N A and Rob W M V S. 2002. Systema Porifera A Guide to the Classification of Sponges. Queensland (AU): Kluwer Academic/ Plenum Publ. New York.

Hutomo M \& Anugerah N. 2014. Panduan Monitoring Padang Lamun. Pusat Penelitian Oseanografi Lembaga Ilmu Pengetahuan Indonesia. Jakarta: PT. Sarana Komunikasi Utama.

Ira, Oktama D, Juliati. 2012. Kerapatan dan Penutupan Lamun pada Daerah Tanggul Pemecah Ombak di Perairan Desa Terebino. Provinsi Sulawesi Tengah. Aquasains. 1:90-95.

Irfan M M. 2018. Hubungan Morfotipe Lamun dan Spons di Perairan Pulau Pramuka, Kepulauan Seribu. Bogor: Departemen Ilmu dan Teknologi Kelautan, Fakultas Perikanan dan Ilmu Kelautan Institut Pertanian Bogor.

Remya T A., Thomas., Devanand P., Kavlekar dan Ponnapakkam A. Loka Bharathi. 2010. Marine Drugs from SpongeMicrobe Association-A Review. Marine Drugs. 8: 1417-1468. ISSN 1660-3397.

Rizki P I \& Yuni E H. 2018. Artikel Tinjauan: Aktivitas Antikanker Spons Laut Kelas Hexactinellida. Farmaka Suplemen. Vol. 16 (2): 347-352.

Samira M I., Dietriech G B., Ocky K R \& Mujizat K. 2016.Komposisi dan Aktivitas Antibakteri Spons Laut dari Ekosistem Lamun yang Berbeda di Perairan Kepulauan Seribu, Jakarta.Jurnal Ilmu dan Teknologi Kelautan Tropis. Vol. 8 (2): 729-745.

Sugiyono. 2013. Metode Penelitian Pendidikan Pendekatan Kuantitatif, Kualitatif dan R $\&$ D. Bandung. Alfabeta.

Suharyanto. 2008. Distribusi dan Persentase Tutupan Sponge (Porifera) pada Kondisi Terumbu Karang dan Kedalaman yang Berbeda di Perairan Pulau Barrang
Lompo, Sulawesi Selatan. Biodiversitas. Vol 9 (3): 209-212. ISSN: 1412-033X.

Suparno., Dedi S., Neviaty P Z \& Rachmaniar R. 2009. Transplantasi Spons Laut Petrosia Nigricans. Ilmu Kelautan. Vol 14 (4): 234-241. ISSN 0853-7291.

Tebaiy S., Fredinan Y., Achmad F dan Ismudi M. 2014. Struktur Komunitas Padang Lamun dan Strategi Pengelolaan di Teluk Youtefa Jayapura Papua. Jurnal Segara. Vol 10 (2): 137-146.

Webster N S. 2007. Sponge disease: a Global Threat. Environmental Microbiology Vol. 9 (6): 1363-1375.

Triatmodjo B. 1999. Teknik Pantai. Beta Offset. Yogyakarta.

Wulff J L. 2008. Collaboration Among Sponge Species Increases Sponge Diversity and Abundance in a Seagrass Meadow. Journal Marine Ecology. 29: 193-204. 